\title{
Defining Due Process Down: Expedited Removal in the United States
}

\author{
Stephen M. KNight
}

\begin{abstract}
Canadians debating the merits of restricting access to the national territory by asylum seekers and others should consider the experience of the United States with its new expedited removal process. Three years after its enactment, U.S. immigration authorities have come to rely on expedited removal. Yet many troubling questions have been raised about the treatment by immigration officers of individuals in expedited removal and about the impact of the mandatory detention of asylum seekers. A particular concern arises from the elimination of the fundamental safeguard of judicial review.
\end{abstract}

\section{Résumé}

Les Canadiens qui débattent la question de savoir s'il faut ou non limiter l'accès au territoire national aux demandeurs d'asile et autres personnes, devraient prendre le temps de considérer l'expérience des États-Unis avec leur procédure de renvoi accéléré. Trois ans après sa promulgation, les officiels du Département américain de l'immigration sont arrivés à dépendre sur le renvoi accéléré. Cependant, beaucoup des questions troublantes ont été soulevées à propos du traitement que reçoivent les personnes en renvoi accéléré aux mains des officiers $d u$ Service de l'immigration et à propos de l'impact de la détention obligatoire des demandeurs d'asile. Une raison particulière de s'inquiéter provient de l'élimination de la sauvegarde fondamentale du recours judiciaire.

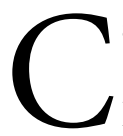
anadians debating the methods and merits of restricting access to their national territory by asylum seekers and others should consider lessons from the experience of its southern neighbour. In 1996, through the enactment of "expedited removal," the United States Congress sharply redefined-downward-what process is due an individual who arrives at its border and is deemed not to have proper documents to enter. The laws, first implemented on April 1, 1997, were among the most controversial provisions of the Illegal Immigration Reform and Immigrant Responsibility Act of 1996 (IIRIRA) and constitute one of the most fundamental changes in U.S. immigration law and policy in many decades. After more than three years of experience with the expedited removal process, many questions have been raised about the treatment of individuals by officers of the U.S. Immigration and Naturalization Service (UsINs), about the mandatory detention of asylum seekers, and particularly about the impact and effect of the elimination of any judicial review. Many immigration officers seem very much aware of the unreviewable finality of their actions, and behave accordingly.

Issues likely to be of particular interest in Canada include problems encountered in efforts to report on or observe the exercise of these unprecedented powers by immigration authorities, the extent to which usins has come to rely on expedited removal, and the impact of expedited removal on Canadian-bound asylum seekers.

\section{Expedited Removal: Unprecedented Unreviewable Authority}

Expedited removal applies to all non-citizens arriving in the United States who do not have valid or suitable travel documents, or who attempt entry through fraud or misrepresentation. ${ }^{.}$Should a question arise about the documents presented by an applicant for admission, the indi- 
vidual is referred to "secondary inspection" for an interview. In the vast majority of cases, the final decision on a person's case is made during this interview at the port of entry. With the concurrence of a supervising officer, the individual is issued a five-year bar on entry to the United States, and then promptly-often immediately-removed. ${ }^{2}$ The port officers' determination is not subject to review by an administrative immigration judge, federal appeals court, or any other body. ${ }^{3}$

The U.S. Congress did seek to provide a limited amount of additional process to two groups subject to the expedited removal laws: asylum seekers and persons who claim a legal right to remain in the United States.

First, Congress created a procedure to screen the claims of asylum seekers at the border to decide if they will be permitted access to the U.S. asylum determination process. UsINS officers conducting secondary inspection interviews are required to ask all individuals being found inadmissible whether they have a fear of return. ${ }^{4}$ Those who express such a fear are to be detained and referred to a screening interview. At this interview, which generally takes place within a matter of days after the attempted entry, a UsINs asylum officer is to determine if the asylum seeker has a "credible fear" of persecution. Under this standard, an individual must establish that "there is a significant possibility, taking into account the credibility of the statements made by the alien in support of the alien's claim and such other facts as are known to the officer, that the alien could establish eligibility for asylum ..." ${ }_{5}$ There is little role for legal assistance in this process, ${ }^{6}$ even if an asylum seeker has sufficient time and money to obtain such assistance.

An individual determined not to have a "credible fear" may request a limited form of administrative review by an immigration judge (IJ). The IJ review generally takes place within a few days of the asylum officer's decision, during which time the applicant remains detained. There is no appeal from this decision. ${ }^{7}$ Access to appellate review by the national Board of Immigration Appeals - which normally reviews decisions made by IJs - and, beyond that, to federal court, is barred by law. ${ }^{8}$

Second, persons who claim to have lawful status in the United States-including U.S. citizens, legal permanent residents, and persons with refugee status - are to be detained and referred to an immigration judge for consideration of their claims. ${ }^{9}$ The IJs determination of the issue is final; there is no appellate review. ${ }^{10}$ Those who fail to establish a "credible fear" during the process, or whose claims to lawful status are not verified by an inspector or immigration judge, are summarily removed from the United States.

As passed by Congress, the expedited removal laws may be applied not only to persons apprehended at ports of entry but also to persons who entered the U.S. without inspection and cannot establish that they have been physically present for two years. ${ }^{11}$ Usins has announced a plan to set up a pilot program, aimed at a specific criminal population, ${ }^{12}$ to begin the exercise of this authority to extend these broad powers beyond the ports of entry and to use them to remove persons from within the United States.

\section{Efforts to Observe the Process}

usins has resisted efforts to observe and monitor the implementation of its unprecedented new powers. Nongovernmental organizations (NGOs) such as the Lawyers Committee for Human Rights and Amnesty International have been refused access to observe the expedited removal process. The Office of the United Nations High Commissioner for Refugees (UNHCR) has been granted limited access to primary data and on-site observations, but only on the condition that its observations remain confidential. ${ }^{13}$ As of October 2000, after two and a half years of expedited removal, the UNHCR had observed a total of two secondary inspections, and the General Accounting Office (GAO) in its recent report witnessed seven. ${ }^{14}$ In combination with the unprecedented elimination of judicial review, this amounts to a total absence of independent oversight over a process under which 99 per cent of persons were removed from the U.S. at secondary inspection, ${ }^{15}$ often the same day of their arrival.

The Expedited Removal Study was created in 1997 to investigate the implementation of these unprecedented procedures, especially as they apply to asylum seekers. The Study had planned to engage in a comprehensive statistical analysis of data, together with extensive on-site observation at ports of entry. But the Study's ability to report on the process has been restricted by the usins's denial of access. Instead, the Study collected data from NGos and attorneys that represented individuals subject to the expedited removal process, building a database of up to 100 variables from 924 individual cases over three years. ${ }^{16}$ After filing suit under the Freedom of Information Act together with the Immigrants' Rights Project of the American Civil Liberties Union (ACLU), the Study also obtained and analyzed statistics on expedited removal produced by the UsIns. ${ }^{17}$ The Study released annual reports on expedited removal in May 1998, 1999, and 2000, ${ }^{18}$ and its evaluation 
of the GAO's September 2000 report on expedited removal was released in October 2000. ${ }^{19}$

Congress has twice passed legislation asking its investigative arm, the GAO, to report on expedited removal and determine, among other things, if asylum seekers are being incorrectly being sent back to their persecutors. ${ }^{20} \mathrm{Un}$ fortunately, the GAO's reports have focused on UsINs management controls rather than on-site observation andjust as important- did not seek to evaluate the quality or accuracy of decisions made by usins during the process. ${ }^{21}$ As a result, Congress's questions remain largely unanswered, and it remains the case that today, nearly four years after its implementation, the public has been provided with little information on the manner in which expedited removal is being administered.

\section{Expedited Removal in Practice}

The central unanswered question about expedited removal remains the conduct of secondary inspection.

The Study and other NGos have documented many troubling case studies of abuses and mistakes by usins officers. ${ }^{22}$ To summarize a few of the cases:

- A young man from Algeria who had suffered detention and torture in his home country alleges that he was repeatedly threatened with immediate return by an Ins official after he requested asylum. He became so desperate at the thought of being sent back that he stabbed himself in the abdomen, requiring emergency treatment.

- Two Chinese asylum seekers-one fleeing religious persecution, the other punishment for violation of family planning laws - were criminally prosecuted for their use of false U.S. passports; convictions could have rendered them ineligible for asylum.

- A native-born U.S. citizen, accused of making a false claim to U.S. citizenship, was threatened with twenty years imprisonment, left to sleep on the floor in a detention area at the airport, and then imprisoned for over six weeks before his claim to citizenship was validated by an immigration judge.

- A mother and daughter from a Peruvian family that had suffered multiple death threats from a guerrilla group arrived in the U.S. and requested asylum. The two were immediately separated, and the mother, who was detained in a criminal facility, made a decision to abandon her claim after she was told that she faced many weeks of detention and continued separation from her daughter. Her husband has since been granted asylum in the United States.
- A Coptic Christian asylum seeker fleeing religious persecution in Egypt alleges that an INs officer expressed hostility and religious bias during secondary inspection, which frightened him into retracting his claim for asylum. ${ }^{23}$

Another troubling aspect of expedited removal is its application to individuals with facially valid travel documents, such as a person with a tourist visa suspected of an intent to work in the United States. The Study has documented cases of refusals to admit persons to the U.S., based on questionable judgment calls or mistaken understandings of the controlling law. ${ }^{24}$ One Mexican teenager who was spending the summer in Texas with her sister, her sister's husband, and their baby, before attending college in Mexico, was found inadmissible on the ground that she was helping to care for her infant niece-an activity judged, incorrectly, to be incompatible with a tourist visa. ${ }^{25}$

In addition, widely varying rates in the application of expedited removal at the northern and southern borders and at different ports of entry, noted both by the Study and by the GAO, raise questions about whether uniform legal criteria are being applied in a non-uniform manner. Immigration officers have the discretion to allow individuals they judge inadmissible to withdraw their applications for admission and depart the port of entry without being issued an order of removal and its five-year bar on entry. ${ }^{26}$ usins has reported significant variation in withdrawal rates-from 27 per cent at southern (Mexican) land ports to 95 per cent at northern (Canadian) land ports. The rate at airports was 39 per cent. ${ }^{27}$ And the Study has documented striking variations in the percentage of expedited removals for different major nationalities and ports of entry. ${ }^{28}$

Further concerns about expedited removal have been raised because of its impact on individuals other than asylum seekers. There are many reports of U.S. citizens of Hispanic and African-American ethnicity who have been questioned, detained, and even removed from the United States. ${ }^{29}$ The actions of usins officers implementing expedited removal have also raised controversy about the treatment of business travellers and tourists. ${ }^{30}$ And of course the most notable impact of expedited removal is on the U.S.-Mexican border and on Mexicans and MexicanAmericans.

One troubling finding is the extent to which expedited removal has quickly become a central pillar of usins policy. Approximately half of all removals from the U.S. in fiscal years 1999 and 2000 were made under expedited removal's abbreviated procedures. ${ }^{31}$ While the legislation to enact expedited removal was proposed, justified, and attacked 
almost entirely as a strategy for handling fraudulent asylum claims,,$^{32}$ in practice, expedited removal appears to be in large part about exercising control over the U.S.-Mexico border. One land port of entry near San Diego, California-San Ysidro-accounted by itself for fully 44 per cent of all expedited removals over the first three years of the law's application. ${ }^{33}$ And nine of the ten ports of entry with the highest numbers of expedited removals are land ports on the U.S.-Mexico border; together, these entry points made up over 80 per cent of all expedited removals. ${ }^{34}$

However, the fact that the overwhelming number of individuals subjected to expedited removal are Mexican nationals should not deflect attention from the law's impact on asylum seekers. The GAO found that 19 per cent of those arriving at U.S. airports and placed in expedited removalone out of every five persons-expressed a fear of being returned to their homeland. And for these asylum seekers, the law's lightening-fast procedures coupled with the absence of any judicial review constitute a troubling new obstacle to be overcome before they may find safety. ${ }^{35}$

\section{Credible Fear}

The Study has consistently raised questions about the adequacy of expedited proceedings for making complex determinations in asylum cases, such as whether the claim has a nexus to one of the five grounds for asylum..$^{36}$ As noted above, the credible fear interview is an initial screening process to determine whether a person should be permitted to apply for asylum, and it is not intended to be a full asylum hearing. ${ }^{37}$ However, "nexus" or "on account of" determinations can involve highly complicated factual and legal issues that may well be aided by fuller factual development than is possible in the expedited removal process.

The percentage of individuals passing their credible fear interviews has risen from 82 per cent in fiscal year 1997 to 98 per cent in $1999 .{ }^{38}$ But this fact does not eliminate concerns over the fact that the credible fear regime has no basis in international law and in its implementation may place the U.S. in violation of its responsibilities under the Refugee Convention. On its face, the "significant possibility" requirement $^{39}$ is a far higher standard than the "manifestly unfounded" test that the UNHCR has suggested countries may employ; the UNHCR has submitted that such a standard should be used only to screen out claims that are "so obviously without foundation as to not merit full examination at every level of procedure." ${ }^{\circ 0}$ The high passage rate may indicate that the credible fear regime is currently operating as something like a "manifestly unfounded" test.
But it also indicates that the legislation's concern with supposedly large numbers of people abusing the U.S. asylum system was unfounded.

Recently, the usins drafted regulations that would permit asylum officers to grant asylum after a credible fear interview to persons who have established not only a credible fear of persecution, but also the higher standard of "well-founded fear" required for asylum. ${ }^{41}$ Such a rule could move the U.S. still further away from the international "manifestly unfounded" standard by investing further substantive importance to what is supposed to be a screening interview. A few asylum seekers would certainly benefit from an early grant and release from detention. But the holding of an in-depth interview at this early stage of the process - when legal representatives and live interpreters are rarely present and applicants may be hesitant to speak about the trauma they have suffered - could well result in adverse consequences to the great majority of asylum seekers who will not be granted asylum at the credible fear interview.

\section{Canadian-Bound Asylum Seekers}

A notable consequence of expedited removal, one that was presumably unintended, is its impact on Canadian-bound asylum seekers who seek to transit through the United States. Many people who seek to travel to Canada through the U.S. have been placed in expedited removal, including a large number of Sri Lankans with relatives in Canada; the irony is that a process designed to screen people out instead may leave them with no option but to attempt to remain in the United States. The resulting transnational migration policy issues have occupied the attention of numerous refugee advocates in Canada and the United States and, to a lesser extent, the immigration authorities in both countries..$^{42}$

Before the enactment of expedited removal, individuals were relatively free to travel through the U.S. by land or air to neighbouring countries. Today, persons seeking refugee status in other countries who transit through the United States may be placed in expedited removal proceedings. In order to avoid immediate removal and return, such a person must immediately identify herself as an asylum seeker, be referred to an asylum officer, and be found to have a credible fear of persecution. Once this hurdle has been passed, the individual will be detained and must apply for release via parole. While usins parole policies vary in different regions, few if any asylum Canadian-bound individuals appear to have been paroled in the majority of usins districts. The New York district, through which a great 
number of these asylum seekers attempt to transit, is renowned among immigration advocates for its restrictive parole practices.

Those not granted parole must apply for asylum in the United States in order to avoid removal to their country of citizenship or residence. A grant of asylum in the United States is a bar to eligibility for refugee status in Canada, ${ }^{43}$ and may preclude a person from reuniting with family and friends or living in a region where he or she has community ties. Thus, the practice of placing Canadian-bound refugees in expedited removal and detaining them raises significant humanitarian and policy concerns.

Refugee advocates point to international law in support of their position that asylum seekers should be permitted to transit through the United States to Canada. The UNHCR has stated that " $[\mathrm{t}]$ he intentions of the asylum seeker as regards the country in which he wishes to request asylum should as far as possible be taken into account," and "[r] egard should be had to the concept that asylum should not be refused solely on the ground that it could be sought from another State . ." 44 And UNHCR has observed that "[i]n application of the principle of the unity of the family and for obvious humanitarian reasons, every effort should be made to ensure the reunification of separated refugee families." 45

This issue has been raised in meetings with Citizenship and Immigration Canada (CIC) and in discussions with the USINS. NGOs suggested that CIC allow asylum seekers detained in the United States to make refugee claims through the Canadian embassy, expedite family sponsorships where the asylum seeker has relatives in Canada, and grant Minister's Permits to allow entrance into Canada. CIC declined to adopt the NGos suggestions, stating,

Canada is committed to upholding humanitarian obligations through our protection and selection systems. At the same time, it is important to control the illegal movement and smuggling of people. In these efforts, cIC works closely with other countries, such as the U.S., with which we have a reciprocal arrangement for the exchange of deportees.

As you will recall, NGo's [sic] in Canada and the U.S. strongly opposed the now defunct responsibility sharing Memorandum of Agreement which had the dual objective of ensuring access to protection in either territory and curtailing "asylum shopping". Neither is there, at this time, a regional regime in place to manage asylum. In the absence of such arrangements, it is difficult to intervene in cases in process in the U.S. While many cases may deserve empathy, the individuals concerned are in a signatory country of the Geneva Convention. ${ }^{46}$
An alternative strategy to aid Canadian-bound asylum seekers involves seeking withholding of removal, rather than asylum, in cases where asylum seekers would meet the higher standard required. Unlike asylum, withholding is generally not a bar to refugee status in Canada, and upon a grant the person may be released from detention and proceed to the border to submit a refugee status claim.

\section{Conclusion}

The expedited removal law has to date been successfully shielded from legal and constitutional challenge. The law as drafted required that any legal action challenging the validity of the expedited removal process had to be filed within sixty days of its April 1, 1997, implementation. ${ }^{47}$ Lawsuits were filed within the deadline, arguing among other things that expedited removal violated protections guaranteed by the U.S. Constitution and international law..$^{4}$ But the challenges were rejected on narrow jurisdictional grounds, ${ }^{49}$ and thus no court has considered the merits of these important arguments. It is difficult to believe that a statute can shield itself from challenge in such a manner, and that no U.S. court will ever address the legality of expedited removal..$^{50}$

Judicial review is a protection generally agreed to be a basic and fundamental check on executive action in order to ensure due process of law, the correction of errors, and the protection of an individual's rights. Unfortunately, the U.S. Supreme Court has ruled that a person seeking admission to the United States has no constitutional rights with respect to her application for admission; the Court has gone so far as to state that "[w] hatever the procedure authorized by Congress is, it is due process as far as an alien denied entry is concerned." ${ }^{11}$ The judicial review-stripping provisions of the expedited removal laws make abundantly clear that the time has come to revisit this troubling precedent..$^{52}$ The alternative may be the gradual acceptance of the elimination of judicial review into other areas of administrative law. ${ }^{53}$ Before Canada considers going down a similar road, it would do well to consider the experience of the United States-lessons that the U.S. has itself yet to learn.

\section{Acknowledgement}

I would like to acknowledge the invaluable assistance of my colleagues Karen Musalo, director of the Study, and Lauren Gibson, the Study's coordinating attorney.

The opinions expressed in this article are my own.

For Natasha. 


\section{Notes}

1. Immigration \& Nationality Act (INA) $\$ 235(\mathrm{~b})(1)(A)(I), 8$ U.S.C. $\$ 1225(\mathrm{~b})(1)(\mathrm{A})(\mathrm{I})$; see also INA $\$ \$ 212(\mathrm{a})(6)(\mathrm{C}) \&(7), 8$ U.S.C. $\$ \$ 1182(\mathrm{a})(6)(\mathrm{C}) \&(7)$. There are limited exclusions to the application of expedited removal, including Cubans who arrive in the United States by plane, 8 C.F.R. $\$ 235.3(\mathrm{~b})(1)(\mathrm{i})$, and unaccompanied minors. Office of Programs, usins, Memorandum: Unaccompanied Minors Subject to Expedited Removal (Aug. 21,1997 ) (on file with author).

2. INA $\$ 212(\mathrm{a})(9)(\mathrm{A})(\mathrm{I}), 8$ U.S.C. $\$ 1182(\mathrm{a})(9)(\mathrm{A})(\mathrm{I})$. The immigration officer has discretion to permit persons to withdraw their applications for admission to the United States and thus avoid this bar on reentry.

3. INA $\$ 235(\mathrm{~b})(1)(C), 8$ U.S.C. $\$ 1225(\mathrm{~b})(1)(\mathrm{C})$ (an order of expedited removal "is not subject to administrative appeal . . ."); INA $\$ \$ 242(a)(2)(A)(I), 8$ U.S.C. $\$ 1252(a)(2)(A)(I)$ ("Notwithstanding any other provision of law, no court shall have jurisdiction to review ... any individual determination or to entertain any other cause or claim arising from or relating to or operation of an order of [expedited] removal ...") \& $242(\mathrm{~g}), 8$ U.S.C. $\$ 1252(\mathrm{~g})$ ("no court shall have jurisdiction to hear any cause or claim by or on behalf of any alien arising from the decision or action by the Attorney General to commence proceedings, adjudicate cases, or execute removal orders against any alien under this Act.")

4. 8 C.F.R. $\$ \$ 235 \cdot 3(\mathrm{~b})(2) \&(\mathrm{~b})(4)$.

5. INA $\$ 235(\mathrm{~b})(\mathrm{I})(\mathrm{B})(\mathrm{v}), 8$ U.S.C. $\$ 1225(\mathrm{~b})(\mathrm{I})(\mathrm{B})(\mathrm{v})$.

6. An asylum seeker may have a consultant present, who "may be permitted, in the discretion of the asylum officer, to present a statement at the end of the interview." 8 C.F.R. $\$ 208.30(\mathrm{~b})$.

7. 8 C.F.R. $\$ 208.30(e)(1)$.

8. INA $\$ 235(\mathrm{~b})(1)(\mathrm{C}), 8$ U.S.C. $\$ 1225(\mathrm{~b})(1)(\mathrm{C})$.

9. 8 C.F.R. $\$ 235.3(\mathrm{~b})(5)$.

10. 8 C.F.R. $\$ 235 \cdot 3(\mathrm{~b})(5)$ (iv).

11. INA $\$ 235(\mathrm{~b})(1)(\mathrm{A})(\mathrm{iii}), 8$ U.S.C. $\$ 1225(\mathrm{~b})(1)(\mathrm{A})(\mathrm{iii})$.

12. See The Expedited Removal Study, "Report on the First Three Years of Implementation of Expedited Removal," Notre Dame Journal of Law, Ethics \& Public Policy, forthcoming, Winter 2000o1: 26 [hereinafter "Third Year Report”].

13. Ibid. at 21 n. 34 .

14. Ibid.; General Accounting Office (GAO), Illegal Aliens: Opportunities Exist to Improve the Expedited Removal Process (GAO/GGDoo-176) (September 200o): 21 [hereinafter “Gao Report"] online: $<$ http://www.gao.gov/>. UNHCR has made clear its opinion that usins should open up the process to national groups. Third Year Report, supra, at note 12.

15. Third Year Report, supra note 12, at 49.

16. Ibid. at 21 .

17. Ibid. at $48-64$.

18. The Expedited Removal Study, Report on the First Year of Implementation of Expedited Removal (May 1998), [hereinafter "First Year Report"]; The Expedited Removal Study, "Report on the Second Year of Implementation of Expedited Removal" (May 1999): Part V(A)(1) [hereinafter "Second Year Report"]; Third Year Report, supra note 12; online: <http://www .uchastings.edu/ers/reports/reports.htm>.
19. The Expedited Removal Study, Evaluation of the General Accounting Office's Second Report on Expedited Removal (October 2000), online: <http://www.uchastings.edu/ers/reports/ reports.htm>.

20. Third Year Report, supra note 12, at 25.

21. General Accounting Office (GAO), Illegal Aliens: Changes in the Process of Denying Aliens Entry into the United States (Washington, DC: GAO, 1998), online: <http://www.gao.gov/daybook/ ooog01.htm>; GAO Report, supra note 14, at 31.

22. See generally First Year Report, supra note 18, Second Year Report, supra note 18, Third Year Report, supra note 12; Lawyers Committee for Human Rights (LCHR), Is This America?: The Denial of Due Process to Asylum Seekers in the United States (October 200o), online: <http://www.lchr.org/refugee/is_ this_america_toc.htm $>$.

23. Third Year Report, supra note 12, Part V.

24. See First Year Report, supra note 18, Part IV (P); Second Year Report, supra note 18, Part V(A)(7); Third Year Report, supra note 12, Part V(F).

25. Third Year Report, supra note 12, Part V(E).

26. INA $\$ 235(\mathrm{a})(3), 8$ U.S.C. $\$ 1225(\mathrm{a})(3)$; Office of Programs, UsINs, Memorandum: Withdrawal of Application for Admission (December 22, 1997) (Attachment 4 to First Year Report, supra note 18).

27. INS, Fact Sheet: FY 1998 Update on Expedited Removals (Washington, DC: INs, June 21, 1999), online: <http://www .ins.usdoj.gov/graphics/publicaffairs/factsheets/expedite.htm $>$.

28. Third Year Report, supra note 12, at 53.

29. One such case involved a Jamaican-American woman reported to have the mental capacity of a five-year-old; she was handcuffed and left overnight in a room at the airport with her legs shackled to a chair before being removed to Jamaica. John Moreno Gonzales, “'This Is a Disgrace'; U.S. Citizen Deported to Jamaica, Kin Charge," Newsday, June 14, 2000; Martin C. Evans et al., "She's Closer to Home, Officials: Deported Woman May Be Back as Early as Sunday," Newsday, June 17, 2000. A Mexican-American man reportedly removed to Mexico without being referred to an immigration judge for a determination of his claim to be a U.S. citizen has filed a tort claim against the United States. See Diaz v. Reno, 4 o F. Supp. 2 d 984 (N. D. Ill. 1999).

30. INs officers at the Portland, Oregon, airport were reported to be refusing entry to applicants nine times as often as at Seattle, and a number of Asian businessmen were jailed and mistreated. "Asians Dub American Airport 'Deportland," Chicago Tribune, April 30, 2000. These incidents received wide coverage throughout Asia.

31. Third Year Report, supra note 12, at 53; Office of Policy and Planning, INs, September 2000 FY Year End Report (October 31, 2000), online: <http://www.ins.usdoj.gov/graphics/aboutins/statistics/ msrsepoo/index.htm $>$.

32. See generally Philip G. Schrag, A Well-Founded Fear: The Congressional Battle to Save Political Asylum in America (New York: Routledge, 2000).

33. Third Year Report, supra note 12, at 54.

34. Ibid.

35. There is a similar trend of rising borders across Europe. See, e.g., James Hathaway, The Emerging Politics of Non-entrée, 1993 
Refugees 91.

36. Third Year Report, supra note 12, at 120; Second Year Report, supra note 18 , at Part V(B).

37. Executive Office for Immigration Review, Interim Operating Policy and Procedure Memorandum 97-3: Procedures for Credible Fear and Claimed Status Reviews 7 (March 25, 1997) (Attachment 10 to First Year Report, supra note 18).

38. GAO Report, supra note 14, at 49.

39. See supra note 5 and accompanying text.

40. UNHCR suggests that states may be justified in "dealing in an expeditious manner with applications which are considered to be so obviously without foundation as to not merit full examination at every level of procedure. Such applications have been termed either 'clearly abusive' or 'manifestly unfounded' and are to be defined as those which are clearly fraudulent or not related to the criteria for the granting of refugee status laid down in the 1951 United Nations Convention relating to the Status of Refugees nor to any other criteria justifying the granting of asy$\operatorname{lum} . . . "$

UnHCr Executive Committee, "Conclusion No. 30: The Problem of Manifestly Unfounded or Abusive Applications for Refugee Status or Asylum," g (d), online: <http://www.unhcr.ch/ refworld/unhcr/excom/xconc/excom3o.htm>

The European Union is considering establishing minimum standards for swift processing of "manifestly unfounded" asylum claims. Migration News Sheet, No. 211/2000 at 7-8 (October 2000).

41. Third Year Report, supra note 12, at 29.

42. Second Year Report, supra note 18, at 120-128; Third Year Report, supra note 12, at 139-143. NGos working on this issue include the Canadian Council for Refugees (CCR), and vive, a Buffalo, NY, refugee advocacy group.

43. Second Year Report, supra note 18, at 121.

44. UNHCR Executive Committee Conclusion 15 (XXX), Refugees without an Asylum Country, gg h(iii), (iv) (1979), online: $<$ http://www.unhcr.ch/refworld/unhcr/excom/xconc/ excom15.htm $>$.

45. UNHCr Executive Committee Conclusion 24 (XXXII) Family Reunification, 1 (1981), online: <http://www.unhcr.ch/ refworld/unhcr/excom/xconc/excom24.htm $>$.

46. Letter from Elizabeth Tromp, director general of Enforcement, CIC, to Janet Dench, executive director, Canadian Council for Refugees (Aug. 16, 1999).

47. INA $\$ 242(\mathrm{e})(3)(B), 8$ U.S.C. $\$ 1252(\mathrm{e})(3)(\mathrm{B})$.

48. American Immigration Lawyers Association (AILA) v. Reno, 18 F. Supp. 2 d 38 (D.D.C. 1998).

49. Ibid., affirmed, AILA v. Reno, 199 F.3d 1352 (D.C. Cir. 2000); see also "District Court Dismissed Expedited Removal Challenges," 75 Interpreter Releases 1403 (October 9, 1998): 1404.

50. See Lisa J. Laplante, "Expedited Removal at U.S. Borders: A World without a Constitution," (1999) 25 N.Y.U. Rev. of Law \& Social Change 213.

51. U.S. ex. rel. Knauff v. Shaughnessy, 338 U.S. 537, 544 (1950).

52. See, e.g., Laplante, supra note 50.
53. The as-yet unimplemented provision allowing application of expedited removal to persons physically present in the United States may provide the first such example. See supra note 12 and accompanying text.

Stephen Knight is research fellow, Center for Human Rights and International Justice, University of California, Hastings College of the Law. Mr. Knight serves as research fellow with the Expedited Removal Study and as coordinating attorney for the Center for Gender \& Refugee Studies. 